\title{
The "hot money" phenomenon in Brazil
}

\author{
MYLÈNE GAULARD*
}

Because of its high interest rates, Brazil attracts more and more speculative capital flows, called "hot money", under the form of foreign loans, direct or portfolio investments. Actually, the country is directly involved in a carry-trade strategy that tends to appreciate the real, what penalizes the Brazilian exportations of manufactured products. Moreover, capital inflows are extremely volatile, and their departure, causing a fall in loans granted to the Brazilian private banks, could provoke a dangerous burst of the speculative bubble they have contributed to form in the Brazilian real estate sector.

Keywords: Brazil; carry-trade; capital inflows; speculative bubbles.

JEL Classification: F32; E44; O54.

\section{INTRODUCTION}

Brazil is proudly emerging from the last global economic crisis with a GDP growth rate of $7.5 \%$ in 2010, a rate never equalled during the last 25 years. On the face of it, Dilma Rousseff, the new President, will enjoy top conditions to carry on with the economic policy initiated by Lula and his Worker's Party (WP) and highlight Brazil as an emerging power that must be taken into consideration as much as China on the international scene. However, such highly optimistic vision of the Brazilian situation should not make us loose sight of the remaining difficulties and especially those increased by the latest global upheavals resulting from the subprime crisis.

This paper will try to emphasize the "carry-trade" phenomenon that has been considerably stimulated by the crisis. Carry-trade is a speculative strategy consisting

\footnotetext{
* Research professor of International Economics, ISTOM, School of Engineers in International AgroDevelopment, Paris (France), e-mail: mylene.gaulard@gmail.com. Submitted: 24/May/2011; Approved: 4/October/2011.
} 
in borrowing funds in countries with low interest rates, to next invest this capital in countries with high interest rates in order to benefit from these gaps and from the appreciation of some currencies. Further to the subprime crisis, Europe and the United States have greatly reduced their rates, thus encouraging speculators to borrow in US dollar and Euro (the "borrowing currencies"), and leading to massive capital inflows that are currently channelled towards a few emerging countries like Brazil, Turkey or South Africa (Jonglez, 2008). The speculative capital flows involved in this strategy can be harmful for an economy, moving very quickly in and out of markets, that is why they are called "hot money". Moreover, because of this carry-trade, Brazil must now face a strong appreciation of its currency and the Brazilian government, getting really worried about this situation, is hence trying to control its capital inflows, notably with the increase since 2009 of the tax on financial operations (Imposição das operações financeiras, IOF).

We will first describe the precise reasons of this carry-trade and attraction of speculative capital (under the form of foreign portfolio investments, loans or direct investments) towards Brazil, then we will underline the weaknesses generated by these massive capital inflows, especially for the development of the productive apparatus. Indeed, these flows foster the Brazilian deindustrialization due to the appreciation of the real and to high interest rates. We will also mention the likely return of a financial crisis should the government fail to properly control the situation. The focus will be made on the deficit of current account and on the nivel of foreign exchange reserves. Eventually, our analysis will focus on the expansion of speculative bubbles promoted by this phenomenon, as well as the present risks of housing bubble burst in Brazil.

\section{BRAZIL, THE NEW TARGET OF CARRY-TRADE}

\section{A short history of carry-trade}

Carry-trade is a speculative strategy that has been used as early as the beginning of the $20^{\text {th }}$ century, when capital left countries with high saving rates, such as France or the United Kingdom, to move towards economies with financing requirements offering high interest rates, such as the United States, Russia, Japan, or the whole of Latin America (Brown, 2008). Until the 1970s, the global economy did not encounter significant carry-trade movements thanks to the equilibrium of the balances of current transactions in a context of fixed exchange rates since the end of World War II. It is only in the 1980s, with the massive orientation of global savings towards the United States to fund a heavy US trade gap, that carry-trade got some strength back, encouraged by the then process of financial deregulation. In the 1990s, speculators took advantage of very low rates in Japan to borrow large sums with the aim to invest this capital in the United States and several developing countries mainly situated in Asia. 
Further to financial crisis in emerging countries, a result of massive withdrawals of foreign capital as early as the mid 1990s (Mexico in 1994, South-East Asia in 1997, or Argentina in 2001), carry-trade, until the subprime crisis, leaned on the Yen and the Swiss Franc as borrowing currencies and used the Australian Dollar, New-Zealand Dollar, Sterling Pound, Turkish Lira, Iceland Krona and Brazilian Real as target currencies (Galati, Heath and Mac Guire, 2007).

Since the subprime crisis, the US Dollar has replaced the Yen as the main borrowing currency (Jonglez, 2008). As a matter of fact, the "quantitative easing" policy set by the US Federal Reserve to supply the market with new liquid assets in exchange for US Treasury Bonds has generated since 2008 the creation of 1,700 billion dollars, combined with very weak interest rates. In November 2010, the second wave of public bonds purchase by the FED forecasts the new emission of 600 billion dollars, a sum that will be mainly directed towards countries offering higher interest rates (Table 1) and with a rising currency, as is the case today in a context of free movement of capital.

Table 1: Key interest rates in main central banks

\begin{tabular}{|l|c|c|c|c|c|c|}
\hline & 2006 & 2007 & 2008 & 2009 & 2010 & 2011 \\
\cline { 5 - 7 } & & & & & & (June) \\
\hline Japan & 0,25 & 0,5 & 0,1 & 0,1 & 0,1 & 0,1 \\
\hline United States & 5,25 & 4,25 & 0,25 & 0,25 & 0,25 & 0,25 \\
\hline Eurozone & 5 & 5,5 & 2 & 0,5 & 0,5 & 0,5 \\
\hline Turkey & 3,5 & 4 & 2,5 & 1 & 1 & 1,25 \\
\hline Australia & 17,5 & 15,75 & 15 & 6,5 & 1,5 & 1,5 \\
\hline South Africa & 6,25 & 6,75 & 4,25 & 3,75 & 4,5 & 4,75 \\
\hline China & 9 & 11 & 11,5 & 7 & 5,5 & 5,5 \\
\hline Indonesia & 6,12 & 7,47 & 5,31 & 5,31 & 5,81 & 6,31 \\
\hline India & 9,75 & 8 & 9,25 & 6,5 & 6,5 & 6,75 \\
\hline Russia & 7,25 & 7,75 & 6,5 & 4,75 & 6,25 & 7,5 \\
\hline Brazil & 11 & 10 & 13 & 8,75 & 7,75 & 7,75 \\
\hline
\end{tabular}

Source: Gecodia, Interest rates at end of period

According to the Institute of International Finance (IIF), emerging countries have thus witnessed an inflow of 908 billion dollars in 2010 (42\% more than in 2009) (Suttle, 2010). These countries, and especially Brazil, South Africa, Russia and India, seem all the more attractive today given the fact that the crisis faced by developed countries has considerably worsened their country risk levels and sub- 
sequent appraisal by rating agencies. China, India and Brazil enjoy today an A3rating in terms of country risk, better than Greece and Ireland (A4) or even Spain and Portugal (A3 with "negative monitoring").

Obviously, this evolution has an impact on the level of exchange rates (Jonglez, 2008), especially in countries that, unlike China, do not try to control their currency appreciation. In Brazil for instance, the Real has gained $40 \%$ against the US Dollar since 2008 (Figure 1). Carry-trade operations then seem particularly profitable given the fact that speculators not only take advantage of the high interest rates of these target currencies, but also gain from their appreciation (Kaltenbrunner, 2010). Indeed, there is an "uncovered interest rate parity", that is to say that the difference in interest rates is more important than the expected change in exchange rates between the countries' currencies, and therefore there is an opportunity to make a profit.

Figure 1:

Export exchange rate Real / Dollar

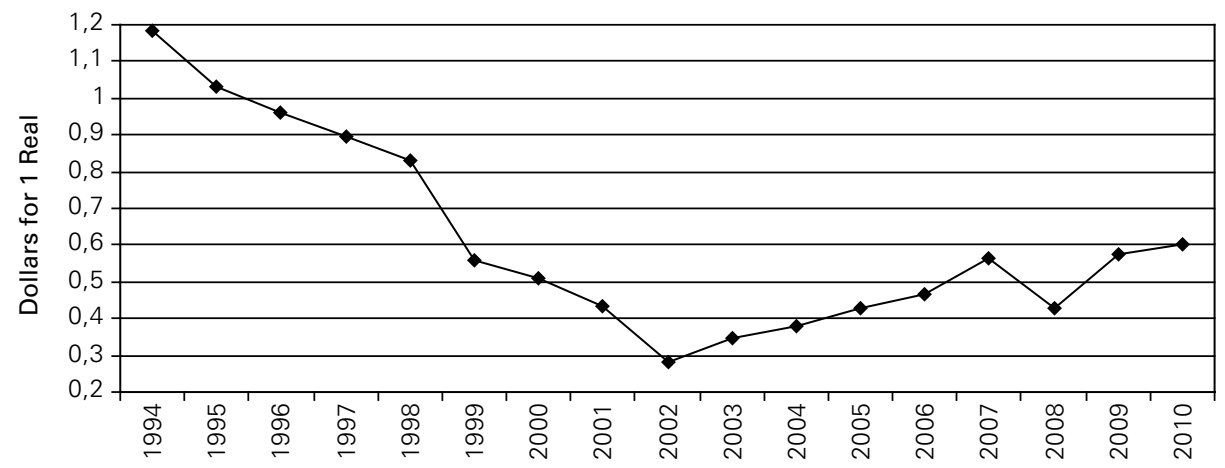

Source: Ipeadata

\section{Brazil, an attractive country for speculative capital}

According to IIF, Brazil received foreign capital valued at 122 billion dollars in 2010, out of a total of 220 billion meant for Latin America; this amount is far exceeding the 47-billion deficit in current transactions (Suttle, 2010). It is quite difficult to assess the overall volume of capital that is directly involved in carrytrade operations, but it is now obvious that the high return on capital proposed by Brazil, coupled with the possibility to borrow large sums in Japan and the United States at very low interest rates, accounts for a large part in the massive inflow of capital since 2006 (Grislain and Jacquet-Saillard, 2008; Kaltenbrunner, 2010).

The key interest rate of Brazil Central Bank reached 12.50\% in July 2011 (against $10.25 \%$ in December 2010), one of the highest key interest rates in the world, while it is respectively $0.25 \%$ and $1 \%$ in the United States and Europe (Table 
1). This high rate is mainly due to the determination of Brazil Central Bank to control the country's inflation. As such, the Bank had to gradually increase its rates to counter an inflation that soared to $5.9 \%$ in 2010 . Obviously, the current price hike is the direct result of the raw materials price leap as well as the rapid growth of a vast Brazilian middle class whose consumption rises by $8 \%$ every year (the famous "Class C", whose incomes range between 1,115 and 4,807 reais, i.e., 470 to 2,029 $€$, representing $54 \%$ of the Brazilian population). Yet, a vicious circle can be observed in the way these massive capital inflows tremendously increase the money supply, thus stimulating price hikes and further encouraging Brazil Central Bank to rise its key interest rate, then attracting more speculative capital, and so on...

Figure 2:

Balance of current operations (in GDP \%)

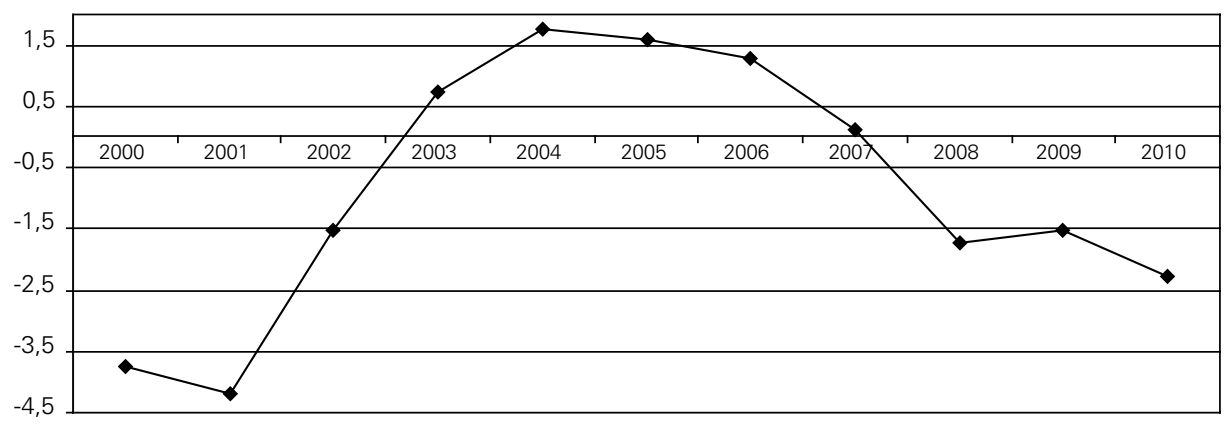

Source: Ipeadata

Since 2004, the Brazilian currency's appreciation can be explained by these inflows of speculative capital, attracted by high interest rates (Araujo and Leite, 2009). While the surplus balance in current operations could stimulate this appreciation between 2003 and 2007, this is not the case anymore since the deficit in current operations reached 2.3\% of GDP in 2010 (against 1.5\% in 2009) (Figure 2). Portfolio investments are experiencing a strong growth (despite a downfall in 2008), rising from 7 to 70 billion between 2005 and 2010, mainly due to the carrytrade phenomenon (Jonglez, 2008), and external loans are rocketing with an external debt of 350 billion dollars in 2010 (against 280 billion in 2009 and 190 billion in 2005) (IEDI, 2011). The net financial account, that includes foreign direct investments (FDI) as well as portfolio investments and external loans, has thus increased from -10 to +100 billion dollars in the same period (Figure 3). Note that the increase in foreign direct investments is much more modest, from 15 billion dollars in 2005 to 50 billion dollars in 2010, although these investments are generally considered as more stable than portfolio investments and external loans, a point that will be later developed in this paper. 


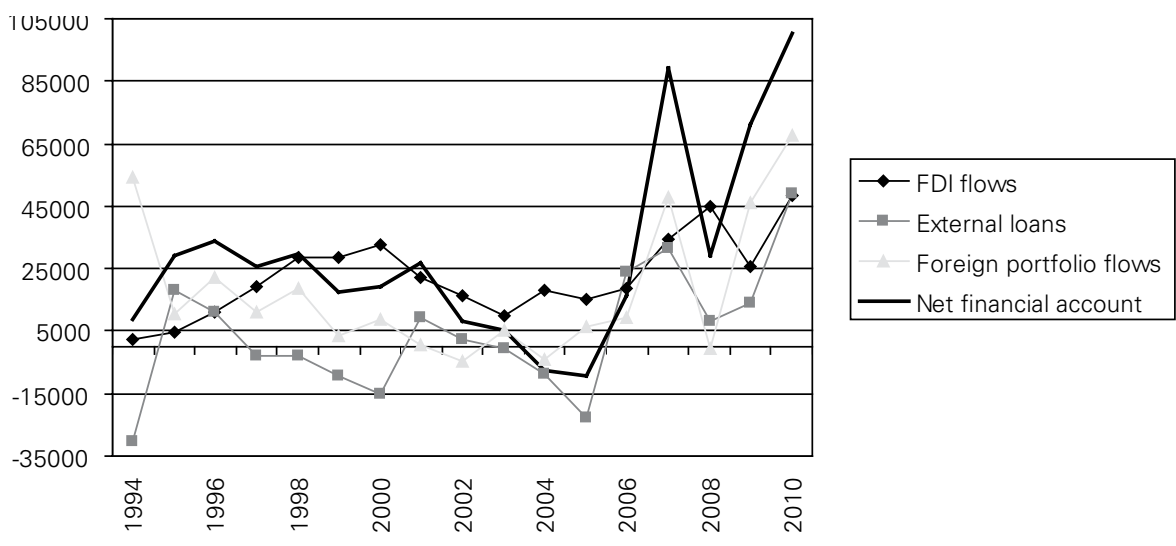

Source: Ipeadata

Besides high interest rates, speculative capital has also been more attracted by Brazil since 2005 because of the growth that has been supported by both Lula's economic policies and the global price leap in raw materials.

Hence, the trade surplus, although on the decline since 2006, still reached 20 billion dollars in 2010; the external debt, public and private, only accounts for $20 \%$ of GDP (against $45 \%$ in 2002), while the public debt only represents $40 \%$ of GDP (against $60 \%$ in 2002) and the primary balance accounts for $2.78 \%$ of GDP; lastly, the consumption enjoys a strong growth thanks to the emergence of a new middle class, while the inflation, below $6 \%$, seems to be controlled. The minimum wage has increased from 240 to 510 reais between 2003 and 2010; meanwhile, the unemployment rate dropped to $7.5 \%$ in 2010 (against over 10\% at the beginning of the decade), and informal work is now representing less than $50 \%$ of active population (against more than 60\% in the 1990s) (Gaulard, 2011, p. 120).

This country, of which $45 \%$ of exports are made of mining and agricultural produce, fully enjoys a favourable international context with record prices for soya ${ }^{1}$, maize and most of raw materials. With a $7.5 \%$ growth reached in 2010 , Brazil looks like a secure emerging power for investors, particularly since a potential drop in raw materials prices has not yet been considered. Brazil's fundamentals are thus very satisfactory, and this explains why the country has been granted the "investment grade" rating by three major agencies, a rating that certifies that there are currently no risks in investing in this country (Bello, 2010).

To illustrate this present trust in Brazil, we note that according to HSBC bank, the Real is the number four-currency for Japan's investments, after the US Dollar, the Australian Dollar, and the Euro. But while Euro and US Dollar have both be-

\footnotetext{
${ }^{1}$ Soya, iron ore, meat, crude oil, sugar and its by-products (especially bio-ethanol), represent $43.4 \%$ of Brazilian exports, against 27\% in 2004 (Valor Econômico, 11 January 2011).
} 
come borrowing currencies because of the low interest rates offered in these two zones, Real, like Australian Dollar, has remained a major target currency for carrytraders since the subprime crisis.

Before we examine the weaknesses generated by carry-trade, we have to consider its beneficial effects and the reasons why an organization like the Institute of International Finance (IIF) blames Brazil for adopting a tax on financial operations ${ }^{2}$. According to IIF, Brazil should keep on encouraging foreign capital inflows rather than taxing them. Indeed, the carry-trade phenomenon leads to a rise in the Brazilian currency, thus reducing the cost of imports and increasing, supposedly, the buying power of Brazilians. Imported disinflation (Ferrari, Arestis and Paula, 2009) is all the more desired in Brazil that the government wants to avoid at all costs the dreadful return of an hyper-inflation that was regularly above 1,000\% per annum until 1994, hampering the development of the means of production. However, as earlier underlined - and we will get back to this in details when we refer to the swelling of speculative bubbles in Brazil —, these massive capital inflows also lead to the expansion of the money supply and as such, they encourage price hikes.

Above all, the other beneficial effect of carry-trade, often put forward, could be its ability to supply new sources of funding to the national economy. Yet, as noted by Manuel R. Agosin and Ricardo Ffrench-Davis (1996, p. 184) as regards Latin America in the 1990s, most portfolio investments occur on the secondary market, only to result in ownership swaps for bonds that have already been issued. To worsen the case, this external funding is extremely volatile (Munhoz and Libânio, 2009), and particularly dangerous when it is at the root of speculative bubbles in the property and/or financial sphere.

\section{STRUCTURAL WEAKNESSES GENERATED BY CARRY-TRADE}

\section{The risks related to the appreciation of the Real}

\section{Means of production that are less and less competitive}

By taxing capital inflows, the Brazilian government attempts to counter the loss of competitiveness of the country's means of production resulting from a strong Real rise since 2003. But it is only from the second half of the 2000s decade that we have been in a position to hold carry-trade responsible for this currency appreciation. Until then, Bresser-Pereira (2008) would rather put the blame on the "Dutch disease" ${ }^{3}$ that was affecting Brazil and several other countries in Latin

\footnotetext{
${ }^{2}$ Ramón Aracena, "Beefing up the arsenal against appreciation”, Institute of International Finance, Washington, 21 January 2011.

${ }^{3}$ The Dutch disease refers to the deindustrialization of the Netherlands in the 1960 s, caused by the discovery of huge gas fields in the North Sea. Indeed, massive gas exports resulted in strong currency appreciation, wage rise and significant labour movements towards this sector, thus hampering the national industry.
} 
America (notably Argentina). Bresser-Pereira considered that Brazil's specialization in the raw materials sector at the expense of its industry was at the origin of a relatively neglected Brazilian industry.

Brazil actually entered a new phase of "deindustrialization" at the end of the 1990 s, a phenomenon encouraged by the strong increase in raw materials prices at international level. In 2000, the share of manufactured and semi-manufactured produce accounted for $74 \%$ of Brazilian exports, but today they only represent $55 \%$ of the country's exports. Just between 2006 and 2008, the exports value increased a great deal $(+27.5 \%)$, although their volume only rose by $2.3 \%$ (Gaulard, 2011, p. 84). This evolution is the direct consequence of an increasing value of staple commodities ( $+43.4 \%$ between these two years) and a strong rise of raw material prices on international markets since the mid 2000s. The surplus balance in current operations that resulted from this evolution between 2003 and 2007 is at the origin of the appreciation of the Real that is hampering the bloom and competitiveness of Brazilian means of production (Sonaglio and Zamberlan, 2010).

Figure 4: Brazil's manufacturing trade balance

(according to technology intensity ${ }^{4}$ of traded goods, in million dollars)

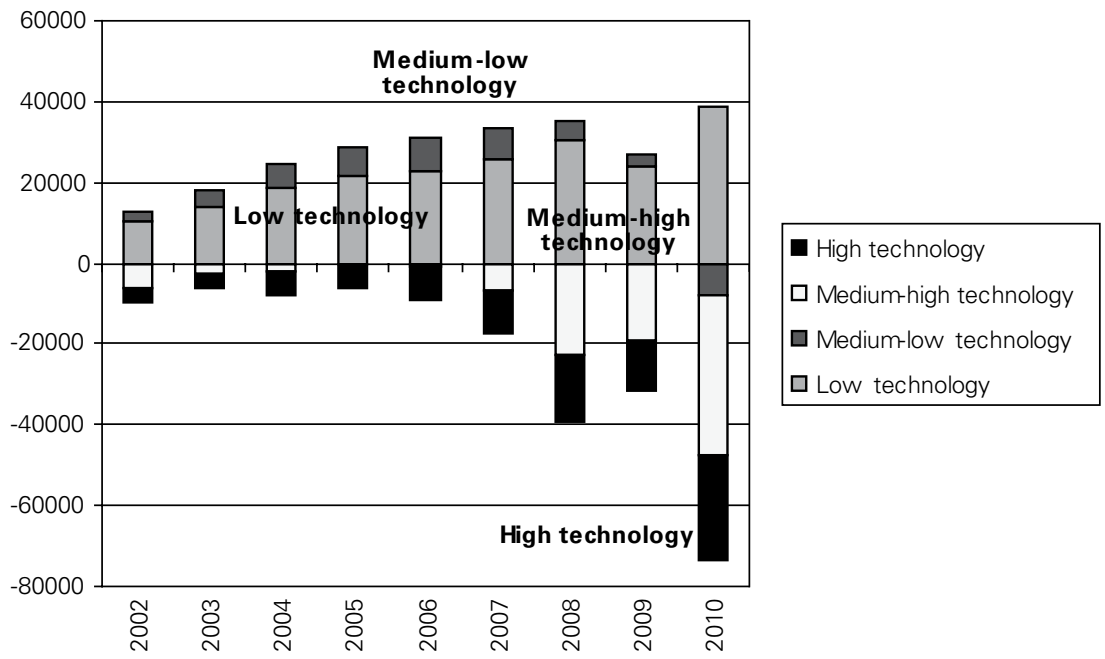

Source: IEDI

\footnotetext{
${ }^{4}$ High technology intensity: aeronautics, information technologies, radio communication.

Medium/high technology intensity: electrical goods, cellulose and paper manufacture, chemicals, car components.

Medium/low technology intensity: leather, plastics, basic metallurgy.

Low technology intensity: extractive industries, food and drink products, textile, wood and furniture.
} 
While the manufacturing trade balance amounted to 24 billion dollars in 2004, the deficit reached 35 billion dollars in 2010, and the situation is even worse for medium/high-tech produce, with a 65 billion dollars deficit (Figure 4). The share of the processing industry in the GDP thus dropped from $36 \%$ in 1985 to $15.5 \%$ in 2009 , and its added value only grew by $3 \%$ between 2000 and 2009 , while China, India and Russia enjoyed much higher growths (respectively $11.5 \%, 7.2 \%$ and 6\%) (Gaulard, 2011, p. 106). In 2010, Brazil's trade surplus is still at 20 billion dollars, but this surplus is mainly resulting from the positive balance obtained with agriculture and mining produce (representing $70 \%$ of this surplus) so that the country can no longer be considered as a large competitive industrial power at international level.

\section{A rise of interest rates heightened by carry-trade operations}

Since 2007, the balance of current operations has been negative and thus cannot bear the entire responsibility for Brazil's Real appreciation. Massive capital inflows have indeed taken over and as such they can be viewed as the main cause of rise of Brazilian currency (Bello, 2010) and loss of competitiveness of Brazilian industry.

Furthermore, even if these capital inflows offer new sources of financing to Brazil's economy and means of production, they are to blame for the rise in money supply and the decision taken early 2011 by Brazil Central Bank to increase interest rates in order to compensate for the country's price hike. We also note that in order to curb the Real's rise resulting from these capital inflows, the central bank buys dollars on the foreign exchange market on a regular basis. This contributes to an ever-increasing money supply, with the subsequent hike in Brazilian interest rates, already among the highest in the world ${ }^{5}$. Yet, the key interest rate that has reached $12.50 \%$ in July 2011 goes along with bank spreads close to $30 \%$; these spreads hamper investments, not only by increasing the debt burden of Brazilian enterprises, but also by limiting the credit offer: the volume of credit represented $80 \%$ of GDP in 1976, against 35\% in 2009 (Gaulard, 2011, p. 109), and it partly explains the fact that the rate of gross fixed capital formation remains below $20 \%$, against $45 \%$ in China.

Because of attractive revenues obtained in the financial sphere, we can see that even large national and foreign companies are gradually developing a financial activity, thus neglecting standard production activities that are far less profitable: in 2009, the 503 largest Brazilian companies drew 53\% of their revenues from the

\footnotetext{
${ }^{5}$ The policy carried out by the central bank is also noxious in so far as it widens the gap between the internal interest rates and the low rates obtained on international reserves owned by the central bank, thus accordingly decreasing its revenues (Griffith Jones, 1998, p. 145). As a result of the weak American rates and dollar depreciation, the return on capital of Brazil's Central Bank is 34\% less in 2009 than what it was in 2008. According to Itaú Unibanco Bank, the losses are valued at 25 billion dollars between October 2009 and September 2010 (Gaulard, 2011, p. 95).
} 
financial sector. Such speculative behaviour is even more blatant in the case of Brazilian banks that abandoned their role in economy financing to recycle into speculative treasure bonds buying, a more profitable activity: while treasure bondsrelated speculation amounted for $4 \%$ of the banks revenues in 1994, it reached $55 \%$ in 2009 (Gaulard, 2011, p. 110).

\section{The dangers related to the instability of capital movements}

\section{The necessity for positive financial balance and the role of FDI}

The relative abandonment and weak competitiveness of Brazilian industry is responsible for a steady increase of the manufacturing trade deficit since 2005 that may soon lead to an adverse trade balance (despite the rising surplus in agrobusiness that reached 76.4 billion dollars in 2010). Such evolution will probably further affect the deficit of the current operations balance that grows bigger and bigger since 2008, to reach 47.5 billion dollars in 2010 (against 24.3 billion in 2009).

While the trade balance is still positive nowadays, the same is not true for the service revenues balance that reached a record deficit of 70.6 billion dollars in 2010 . This deficit is the direct result of an increasing repatriation of profits and dividends as well as a deficit in the service sector linked to Brazilian's expenses in foreign travels, royalties, engineering services, profession fees etc. Out of this 70.6 billion deficit, 31 billion arise out of the deficit in the service sector (against 19 billion in 2009) and the remaining part comes from the expatriation of revenues, profits, dividends and interest.

To avoid drawing upon exchange reserves from the central bank, it is therefore necessary to obtain a positive financial balance that will break even the balance of payments. Foreign direct investments grew up from 15 billion dollars in 2005 to 50 billion dollars in 2010, just enough to cover up for the deficit in the balance of current operations. However, FDI inflows are hampered by high interest rates and Brazilian deindustrialization process; these FDI are increasingly made of intercompany loans that amounted to $23 \%$ of total FDI in 2009, against $0 \%$ in 2005 (data issued from Ipeadata) (Figure 5).

So, the foreign firms also benefit from carry-trade activities through loans made in countries with low interest rates and invested in Brazil; but unlike capital acquisitions in holdings situated on the Brazilian territory, these intercompany loans are extremely volatile and could well encounter a sharp drop in case of carrytrade "liquidation" (Bello, 2008). Moreover, the repayment of these loans goes together with increasing profit repatriation from foreign firms further affecting the balance of current operations in the long run. 
Figure 5: Profit repatriation and intercompany loans of foreign direct investments (in billion dollars)

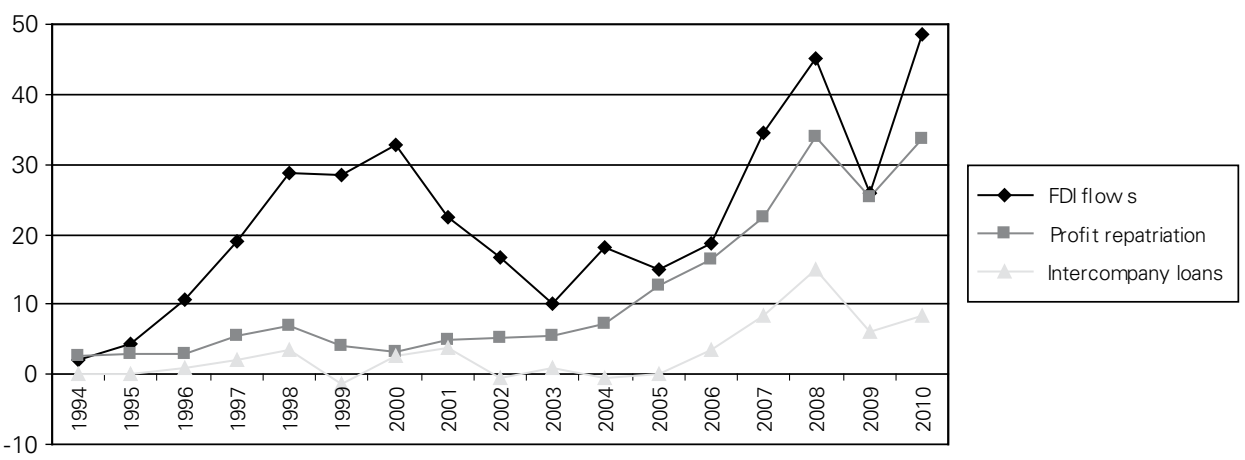

Source: Banco Central

The risks of carry-trade liquidation

Within this financial balance, the portfolio investments, often considered as more volatile than FDI (Brown, 2008, pp. 183-184), enjoyed a strong growth from 0 to 70 billion dollars between 2005 and 2010 (Figure 3). They are even on the way to durably exceed FDI, a phenomenon that did not happen in Brazil since the mid 1990 s. This rise in portfolio investments is the direct result of carry-trade activities, and it is very similar to the risky situation faced by South-East Asia in 1997 (Griffith Jones, 1998).

For instance, a sudden rise of interest rates in developed countries could generate the liquidation of this carry-trade, thus hampering the break-even of the balance of payment through a positive financial balance, to eventually lead to a financial crisis because of massive withdrawals of foreign capital. At the moment, this risk does not seem likely since the exchange reserves of the central bank have reached record heights: the deficit of the balance of current operations represented $75 \%$ of foreign exchange reserves in 1998, while it only accounts for $16.5 \%$ of these reserves in 2010 (Figure 6). So, Brazil presents a negative net public debt, meaning that the country has more external debts than foreign investors have Brazilian public debts. One can thus imagine that in case of carry-trade liquidation, the central bank would use these foreign exchange reserves to break-even the balance of payments (Bello, 2008). 
Figure 6: Foreign exchange reserves and balance of current operations (in million dollars)

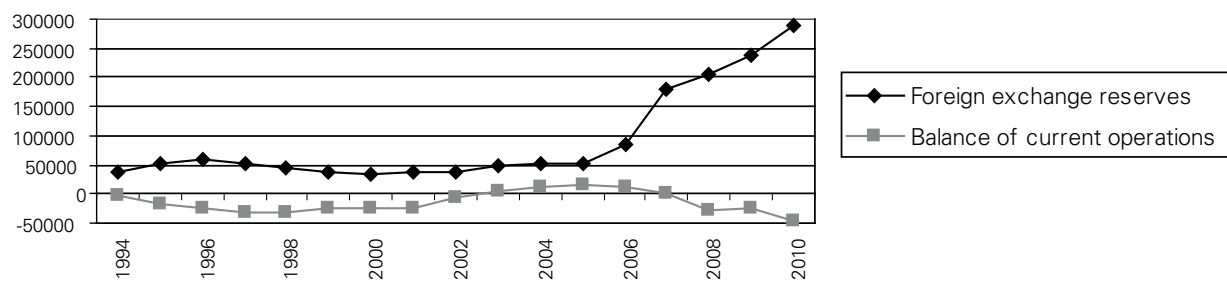

Source: Ipeadata

Such liquidation would also result in a fall of the Real, but because of the current deindustrialization, the country would not necessarily recover a surplus of its balance of current operation in the short term. Today, Brazil's major imports are sustainable consumer goods, fuels or industrial inputs, while the imports of equipment goods, essential for the Brazilian means of production, encountered a lesser progression over the 2000s decade: according to Ipeadata, the imports of sustainable consumer goods have been multiplied by 6 since 2005, while those related to equipment goods essential for the means of production have merely tripled. The increasing imports of semi-manufactured goods also show that domestic suppliers were gradually substituted with foreign manufacturers (Bello, 2010), another sign of Brazil's deindustrialization and vulnerability towards foreign exchange variations (a depreciation of the Real would generate a hike of import prices, without the possibility to replace imported goods with domestic products).

Still, the Brazilian foreign exchange reserves seem to protect the country against any financial crisis and they could well fund the deficit of the balance of current operations in the event of a flight of capital. But this assumption is only valid if this deficit is maintained at levels that are below foreign exchange reserves; and this situation might change due to the degradation of the Brazilian means of production, i.e., in case of fall of raw materials prices or brutal depreciation of the country's currency. So, the main danger of carry-trade for Brazil is not so much the volatility of the capital as the wrong orientation of the latter. While the capital does not promote the upgrading of the Brazilian industry, we will see that it does contribute to the swelling of speculative bubbles, sources of strong instabilities that may question the sustainability of Brazilian growth.

\section{THE SWELLING OF SPECULATIVE BUBBLES}

\section{An international context prone to swelling of speculative bubbles}

\section{Real estate prices increase and financial bubble}

In spite of significant portfolio investments towards Brazil, we must stress that the gross fixed capital formation is still below $20 \%$; this new financing is thus not able to rise the investment rate. In most cases, foreign capital inflows do not con- 
tribute to stimulate the Brazilian accumulation process hence the need to wonder about their orientation in order to better understand what is at stake in carry-trade.

First, we note that the country is currently facing a strong increase in market prices. On São Paulo Stock Market, the Bovespa index got multiplied by 7 since 2002 (Figure 7), a growth that can only be explained by the formation of a financial bubble. The Brazilian Stock Market is now ranked $4^{\text {th }}$ in the world in terms of market capitalization, but unlike other financial markets in developed countries, where over 100 companies have a major stake, $50 \%$ of the Brazilian market capitalization is in the hands of just 8 companies, and a financial bubble burst would probably be much harder for these (Gamble, 2011). The portfolio investments that are currently flowing into Brazil are thus partly to blame for the swelling of market prices and their massive withdrawal represent an obvious danger for the Brazilian financial market.

Figure 7: Bovespa Index

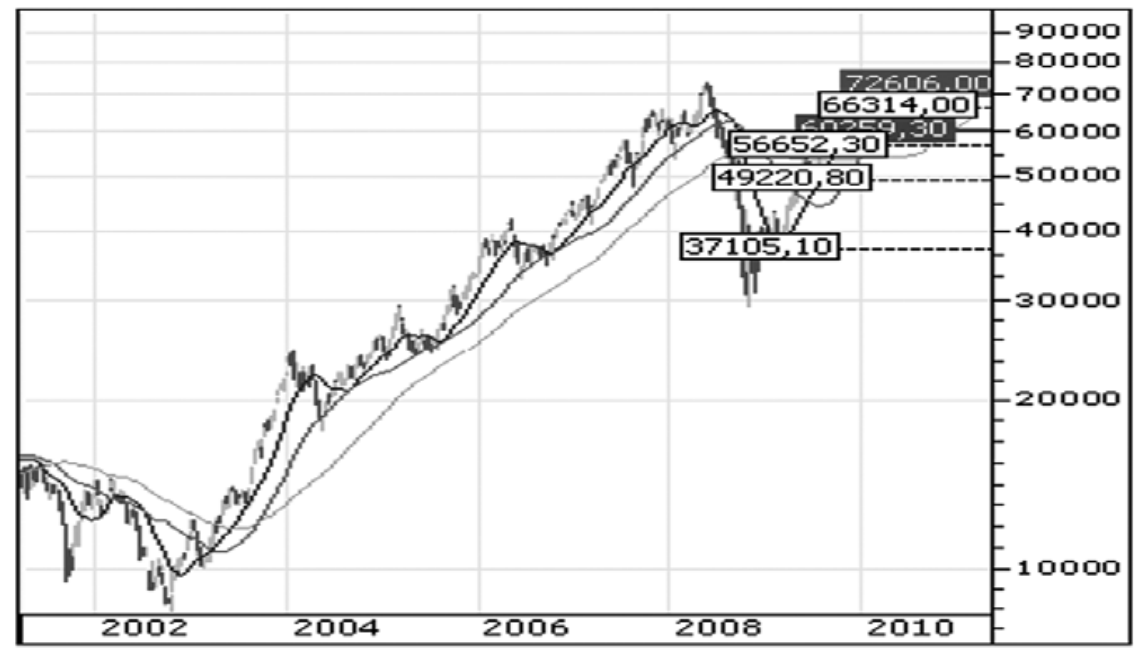

Source: Zonebourse

Yet, what is particularly interesting here is the swelling of the Brazilian housing bubble since it concerns more Brazilians than the financial bubble does. Its potential burst could have more serious consequences in a greater number of sectors. Indeed, the last 3 years have seen huge foreign direct investments in the real estate sphere, a flow that has contributed to the swelling of this bubble: according to SOBEET ${ }^{6}$, the Brazilian Society for Studies of Transnational Companies, real estate FDI have grown from 4.8 billion dollars in 2009 to 12 billion in 2010. According to a survey made by the Association of Foreign Investors in Real Estate ${ }^{7}$, Brazil

\footnotetext{
${ }^{6}$ SOBEET = Sociedade Brasileira de Estudos de Empresas Transnacionais e da Globalização Econômica.

${ }^{7}$ AFIRE (Association of Foreign Investors in Real Estate), "Interest in emerging real estate markets broadens”, 3 January 2011.
} 
seems to be the most promising emerging country in 2011 , and is ranked $4^{\text {th }}$ among the most attractive countries in the world.

It is quite hard to appraise the evolution of property prices in Brazil since the indicators created for this purpose are still very recent. For that matter, the government and IBGE, the Brazilian Institute of Geography and Statistics, are trying to have their own indicator set up by the end of the year. At the moment, we can refer to indexes from Bovespa, Getulio Vargas Foundation and IGMI-C ${ }^{8}$ (General Index of Commercial Property Market) to analyse the evolution of the commercial property market. As for the residential property market in large cities, we can refer to the FipeZap ${ }^{9}$ index created by FIPE (Foundation Institute of Economic Research), but only from 2008. According to these indicators, the prices of residential property have increased by an average $80 \%$ in Brazil's major cities since 2008 (95\% in Rio de Janeiro and 79\% in São Paulo) (Figure 9). As for commercial property, the prices have risen by $280 \%$ since 2000 (Figure 8).

This evolution on both residential and commercial property market cannot be merely explained by Brazil's economic growth and wage bill increase. As a matter of fact, over the last 7 years, the National Index of Construction Costs (NICC) rose by $63 \%$ while the average real effective income of Brazilians only grew by $22.65 \%$ (Ipeadata), showing a widening disconnection between the property prices and the rest of the economy. Employment in civil construction has indeed increased by $80 \%$ between December 2003 and September 2010, while it only rose by 31\% in the processing industry and $36 \%$ in other sectors (Ipeadata). This enthusiasm for Brazilian real estates has been all the more stimulated over the last years that the country is due to receive the World Football Cup in 2014 and the Summer Olympic Games in 2016.

Figure 8: Evolution of commercial property prices (base 100 in January 2000)

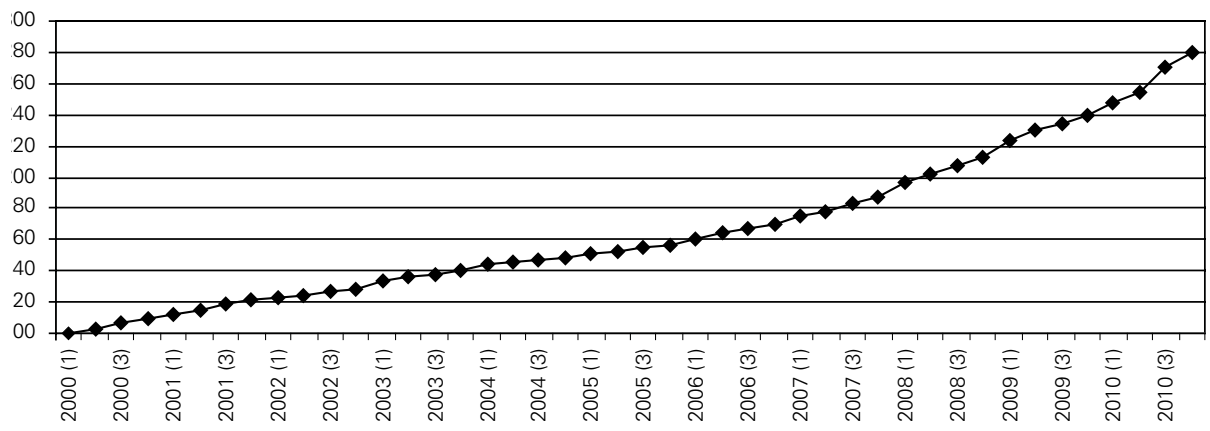

Source: Bovespa, Getulio Vargas Foundation.

\footnotetext{
${ }^{8}$ IGMI-C: Index on sale and purchase prices, created in 2011. It is based on a sample of 2000 comercial entities in the whole country.

${ }^{9}$ FipeZap: Index on sale prices, created in 2011. It is based on real-estate ads in São Paulo, Rio de Janeiro, Belo Horizonte, Recife, Salvador, Fortaleza, and Brasília.
} 
Figure 9: Evolution of residential property prices (base 100 in January 2008)

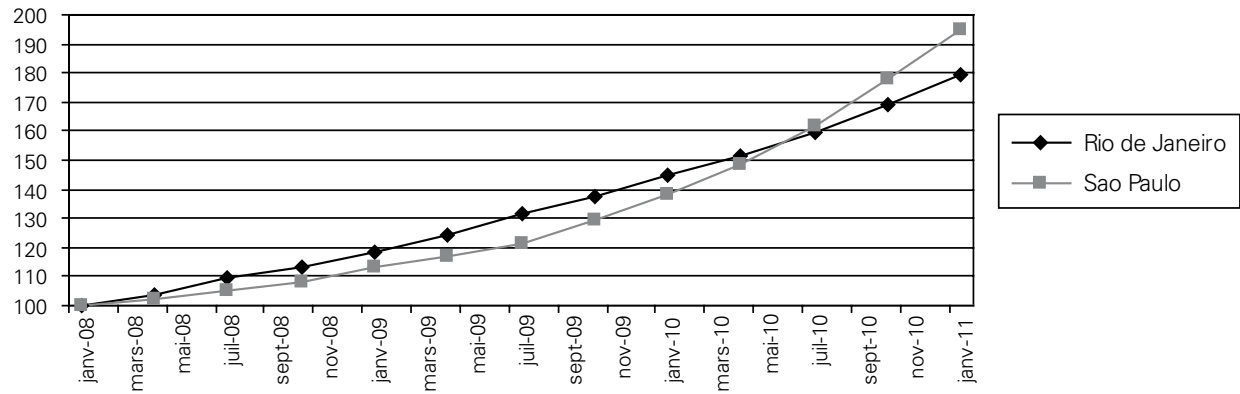

Source: FipeZap

Housing shortages and the role of policies in favour of real estate

Yet, carry-trade is not the only culprit for above-mentioned price hikes. According to the government, the swelling of property prices is not really due to a speculation phenomenon that may quickly turn round, but rather to a significant housing shortage all over the national territory. The number of houses required to properly accommodate the whole population has been estimated at 6 to 8 million. For instance, one third of Rio de Janeiro population is currently living in favelas, and this percentage reaches $40 \%$ in São Paulo and Brasília.

Moreover, the government has set up several programmes to give Brazilians an easier access to home ownership, given that $75 \%$ of households now own their home. When Lula was elected President, his Growth Acceleration Programme (GAP) anticipated 236 billion dollars over 4 years for investments and residential property. The most famous measure taken in 2009, "Minha Casa, Minha Vida" (My House, My Life), plans to bring in 20 billion dollars and help build over 1 million homes. For the same purpose, the loans legal term was extended to 30 years in 2006 (against 12 years in the past), thus leading to a drastic reduction of monthly instalments. Still aiming to make access to home ownership easier, the latest 2009 reforms decided that a property buyer would only become the real owner once his loan has been fully repaid, and this contributes to reassure the banks and encourage them to increase their volume of bank credit. The credit expansion was also encouraged by the key interest rate decrease from $26.5 \%$ per annum in March 2003 to $8.75 \%$ in July 2009, leading to a reduction of banks spreads (see Figure 10). Today, government institutions are even offering loans at $12 \%$ per annum. Lastly, this strong property price increase is also the result of a regained stability of Brazilian economy, combined with the development of a broad middle class. 
Figure 10: Evolution of Brazil's key interest rate and bank spread

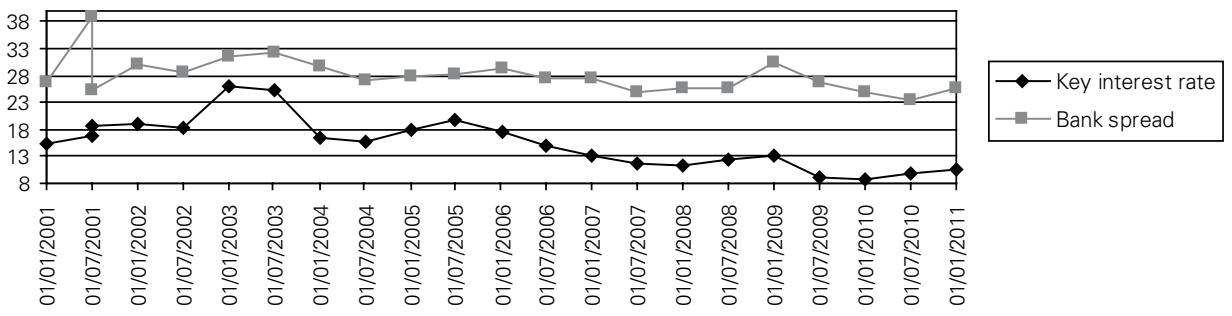

Source: Ipeadata, annualised rates (\% per year)

\section{A highly precarious internal situation}

\section{The role of indebtedness}

As we could see, the current context is prone to a sharp increase in property prices, and the carry-trade phenomenon is not the sole culprit for this evolution. Yet, we must also wonder about the origin of the funds that are currently borrowed since the rise of the private external debt since the mid 2000s has brought to light the increasing dependence of Brazil towards external financing. Between 2006 and 2010, the external debt has indeed increased by 75\% (from 200 to 350 billion dollars) (Figure 11), partly explaining the drastic increase of credit for Brazilian private sector: from $30 \%$ of GDP end of 2006 to over $45 \%$ beginning of 2011 (to reach 990 billion dollars in January 2011) (Figure 12) (Ipeadata). Indeed, the banks' external debt represents $43 \%$ of the total amount of Brazilian external debt in April 2011, against 37\% in January 2009, and it has risen by 63\% between 2009 and 2011 (IEDI, 2011). We will see that this evolution conceals serious weaknesses in Brazilian households debts, which brings us back to our initial assumption, i.e., a housing bubble whose burst could be induced by a sudden withdrawal of speculative capital and that may soon create difficulties for the Brazilian economy.

Figure 11: Brazil's gross registered external debt (in million dollars)

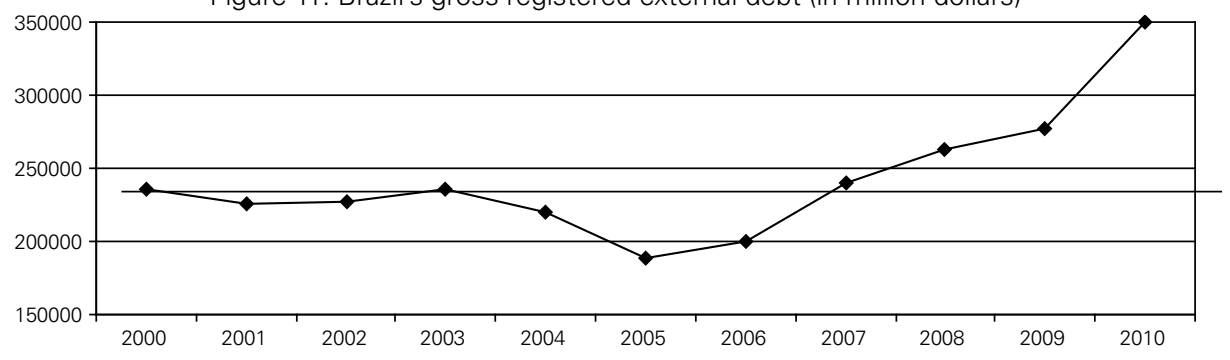

Source: Ipeadata 
Figure 12: Evolution of the private sector credit (in \% of GDP)

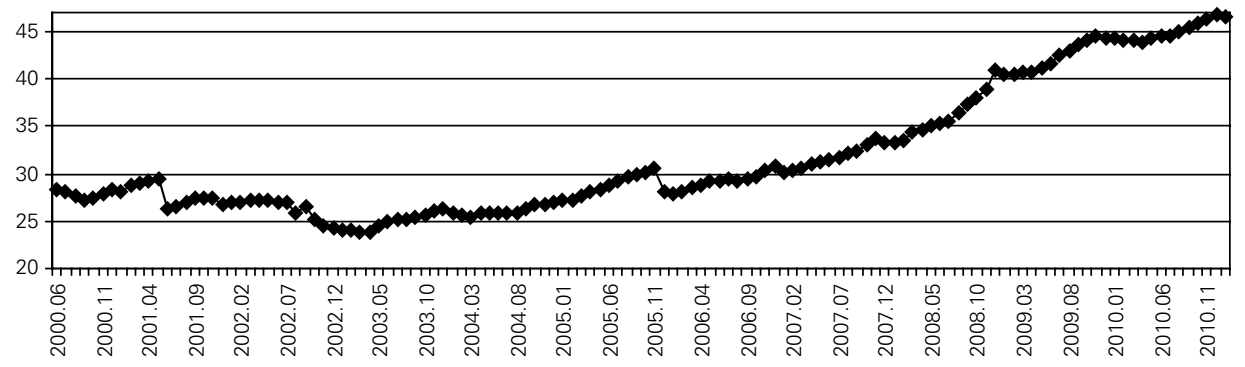

Source: Ipeadata

Over the last 5 years, the Brazilian credit has risen twice faster than the country's GDP (against a ratio of 1.6 and 1.2 for India and China respectively) (Gamble, 2011). According to Itaú Unibanco, the largest private sector bank, the volume of bank credits could even expand by another $20 \%$ in 2011. In this context, although the amount of property loans still remains pretty low, at $2.5 \%$ of GDP (against $78 \%$ in the United States), we have to admit that their progression has been extremely fast (they have been multiplied by 8 since 2005) (Figure 13). In 2004, a mere 321,000 homes were financed through bank credits but this number was increased fivefold in 2009, to reach 1.6 million (of which 900,00 were financed through the "Minha Casa, Minha Vida” programme) (BREP, 2011). This evolution is particularly surprising given the fact that, as earlier mentioned, the interest rates have reached very high levels (the average commercial loan rate is $29 \%$ ).

Figure 13: Brazil's property loans (in million dollars)

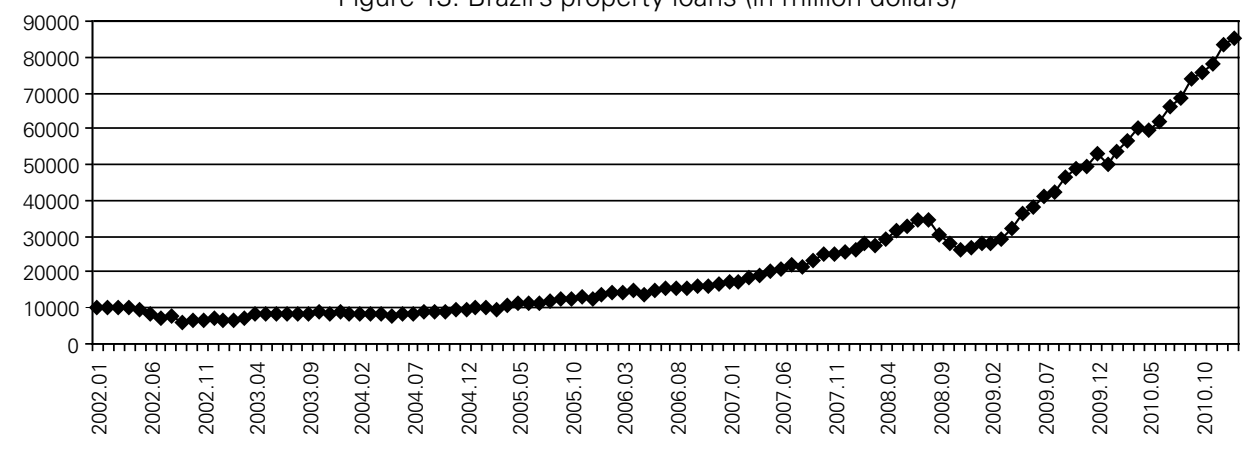

Source: Banco Central

\section{Excessive debt situations}

Debt increases today seem dangerous since the slightest price fall on the property market may create excessive debt situations. The hike in property prices has been exceeding the wage bill growth for the last 7 years (Manarin d'Agostini, 2010), 
and this situation augurs serious difficulties in households' loan repayment in the near future. Yet, according to a survey made by NTF (National Trade Federation) in February 2011, only a few households $(3.6 \%)$ consider that their indebtedness is related to property loans and a vast majority $(71.6 \%)$ think that their debt comes from purchases linked to the possession and wrong utilization of their bank credit card, followed by the purchase of meat $(21.9 \%)$ and the purchase of cars $(10.6 \%)$. As we can see the progression of households global debts has been faster than the property debt (see Figure 14).

Figure 14: Brazilian households debt (in \% of median disposable income)

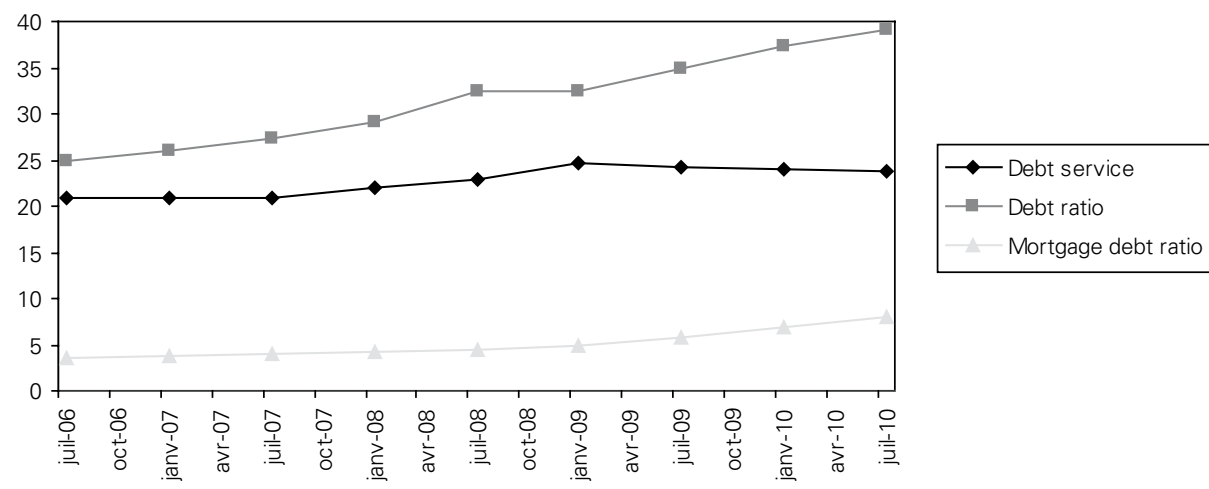

Source: Banco Central, "Relátorio da inflação," September 2010

This stimulation of consumer credit has come along a strong increase of household consumption since the beginning of the 2000 s, with a $7 \%$ increase in 2010 (Figure 15). But a weaker increase of property loans does not ward off dangers of housing bubble burst. We will see that the Brazilian households are already facing difficulties in their loan settlement and a sudden fall in property prices would intensify their financial problems by reducing the value of their assets.

Figure 15: Annual variation of households consumption (in \%)

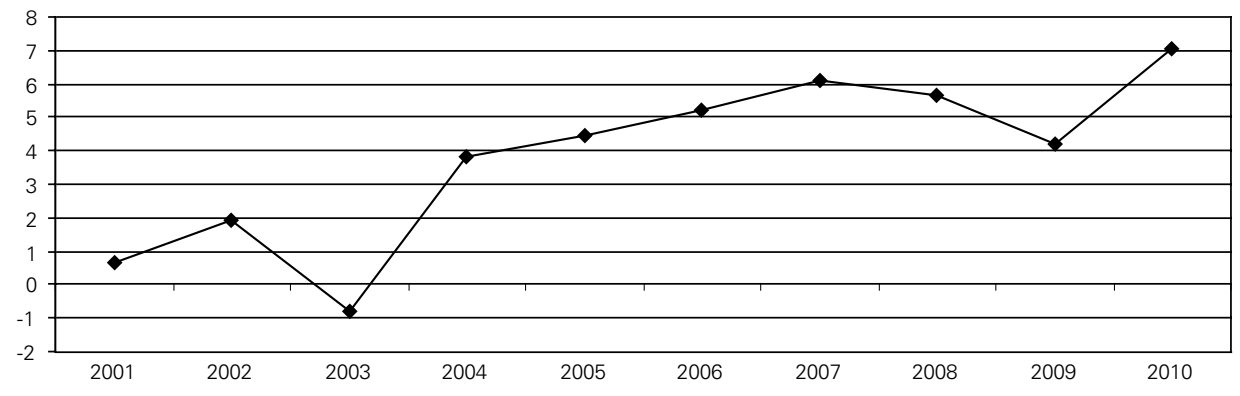

Source: Ipeadata 
According to IEF (Indice das Expectativas das Famílias, i.e., the study of households expectations), an Ipea study dated $1^{\text {st }}$ February 2011 and made on 3,810 households, it is showed that $49.4 \%$ of Brazilian families are currently in debt. What is more, $32.2 \%$ of these families indicated that there are not able to settle their loan, while only $19.2 \%$ consider that they will easily repay their credit (the other ones consider that they can only settle a part of their loan). Brazilian households are still among the less in debt households in the world, but the very high level of interest rates is a heavy burden for the population. Even though the total debt of Brazilian households does not exceed $40 \%$ of their income (against $130 \%$ in the United States nowadays), as shown in Figure 14, the debt servicing of Brazilian households, i.e., the amount due on a monthly basis, is now equal to $25 \%$ of their disposable income, a rather high figure if we compare it to the $14 \%$ figure observed just before the onset of US subprime crisis (Marshall, 2011). According to Brazil Central Bank, the annual interest rates linked to the use of a credit card can be as high as $238.8 \%$, and the average consumption interest rate reaches $47 \%$ in May 2011. Despite their fall over the last years, the level of bank spreads still remains pretty high.

In 2010, the OECD ${ }^{10}, \mathrm{UNO}^{11}$ as well as economist Paul Krugman ${ }^{12}$ told about their fears to witness an excessive expansion of credit in emerging countries in comparison to the wage bill growth, an evolution that could be explained by massive inflows of speculative capital. Brazil was thus included in the OECD's list of risky countries. The big danger would then be that developed countries raise their rates, as planned for year 2012, and that foreign capital abruptly leaves the country. Such evolution would slow down the strong growth of consumer credit, be it on real estate or not, but it would be especially risky because of the subsequent housing bubble burst. Following the path of US housing crisis, Brazil would then have to face an increasing number of excessive debt situations, since many households would not be able to repay their loan through the sale of their assets.

Faced with such risk, combined with the difficulties that could be generated by the flight of capital, the IOF tax on financial operations has thus been increased from $2 \%$ in October 2009 to $6 \%$ in October 2010, in order to further curb foreign capital inflows and better control an overheating economy. A few Asian countries are now encountering the same difficulties, like Korea and Thailand, and they also introduced new taxes on foreign capital inflows, measures that are actually recommended by the IMF (Kokenyne, 2010); this tells a lot about the danger hanging over our global economy because of these capital flows (Griffith Jones and Gallagher, 2011). However, the efficiency of this measure is severely challenged

\footnotetext{
${ }^{10}$ Organisation for Economic Co-operation and Development "OECD Chief warns of asset bubble forming in Brazil", Iowa, 7 February 2010.

${ }^{11}$ United Nations Organization, World Economic Situation and Prospects 2011, New York, 18 January 2011.

${ }^{12}$ La Nación, "Krugman advierte sobre una burbuja brasileña”, Buenos Aires, 6 December 2009.
} 
(Borges and Munhoz, 2010) since the Brazilian currency has kept on increasing over the past 2 years due to massive inflows of portfolio investments.

For this reason, as early as January 2011, the central bank set up a new system to restrain these flows, now forcing the banks to make a $60 \%$ margin deposit on their dollar selling positions when these sales exceed 3 billion dollars. Measures of bank credit restriction have also been recommended by economists from Peterson Institute in order to curb the swelling of speculative bubbles (Subramanian and Williamson, 2010). Furthermore, the latest cut by $0,5 \%$ of the Brazilian key interest rate on the first of September, in order to stimulate economic growth, could slightly slow down capital inflows, as was the cas in Turkey when the Central Bank decided to cut its overnight interest rate at end of 2010. But who knows if this is not too late, since speculative capital has already largely contributed to Brazilian economic overheating; under such conditions, there is more to fear from their flight than from their inflow into the country...

\section{CONCLUSION}

In spite of Brazil's recovery and positive appraisals delivered by rating agencies in 2010, it is unlikely that the country has really come out of the last global economic crisis. Quite the reverse, the expansive monetary policies carried out in developed countries, especially the US, might weaken the economy of the Latin American giant. The American monetary creation and the FED's policy of quantitative easing are indeed at the root of an increasing number of capital flows oriented towards emerging countries like Brazil. This phenomenon is to blame for the Real's overvaluation, reducing the competitiveness of Brazilian exports and increasing the deindustrialization process, thus further widening the deficit of the balance of current operations. Yet, the foreign exchange reserves of the central bank have reached record heights and for the time being, the risk of financial crisis seems pretty low in case of flight of capital in a situation of current account deficit.

The main danger induced by these capital inflows is rather linked to the swelling of speculative bubbles. Most of the time, these inflows are made in the form of portfolio investments that contribute to the swelling of the financial bubble and external loans to the private sector that stimulate consumer loans and households debt. Above all, the value of households' assets has been increased and new loans encouraged by a sudden hike in real estate prices that reached $100 \%$ over the last 2 years in Brazil's largest cities. A housing bubble burst caused by an abrupt exit of foreign capital or internal difficulties might then reveal extreme situations of indebtedness.

We still have to figure out what exactly will induce this capital exit, and it is now essential to revive a vast debate at international level on the point and opportunity to curb the extreme volatility of capital (Palley, 2009; Gallagher, 2011), notably through a tax on exchange operations as proposed by James Tobin in 1972 (Tobin, 1978). 


\section{REFERENCES}

AGOSIN, Manuel R., and Ricardo FFRENCH DAVIS (1996) "Managing capital inflows in Latin America”, in Mahbub Ul Haq, The Tobin Tax, Coping with Financial Instability, Oxford: Oxford University Press, 161-191.

ARACENA, Ramón (2011) “Beefing up the arsenal against appreciation”, Institute of International Finance, Washington, January 21.

ARAUJO, Eliane Cristina de, and Marcos Vinicius Chiliatto LEITE (2009) "Sobre apreciação cambial no Brasil: estimativa, causas e consequências (1994-2008)”, Textos para Discussão, Brasilia, IPEA, n¹404, April.

BELLO DA SILVA, Teresinha (2010) "Déficit em transações correntes: o retorno", Textos para Discussão, Porto Alegre, Fundação de Economia e Estatística Siegfried Emmanuel Heuser, n75, June.

BORGES, Erick, and Vanessa MUNHOZ (2010) "Controle de capitais na economia brasileira: uma análise do IOF como medida de restrição dos influxos financeiros”, Rio de Janeiro, IV Encontro Internacional da Associação Keynesiana Brasileira, August, 3-5.

BREP (Brazil Real Estate Partners) (2011) Brazil Real Estate and Land Investment Guide, São Paulo.

BRESSER-PEREIRA, Luiz Carlos (2008) "The Dutch disease and its neutralization: a Ricardian Approach", Brazilian Journal of Political Economy, vol. 28, n 1, January-March: 47-71.

BROWN, Brendan (2008) Bubbles in Credit and Currency, How Hot Markets Cool Down, New York: Palgrave MacMillan.

BURNSIDE, Craig, Martin EICHENBAUM, and Sergio REBELO (2007) "The return to currency speculation in emerging markets", AEA Papers and Proceedings, vol. 97, n², 333-338.

CNC (Confederação Nacional do comércio) (2011) Pesquisa de Endividamento e Inadimplência do Consumidor, Rio de Janeiro, February.

FERRARI FILHO, Fernando, Philip ARESTIS, and Luis Fernando de PAULA (2009) "A nova política monetária: uma análise do regime de metas de inflação no Brasil”, Economia e Sociedade, Campinas, 18(1):1-30, April.

GALATI, Gabriele, Alexandra HEATH, and Patrick MAC GUIRE (2007) "Evidence of carry-trade activity”, BIS Quarterly Review, September, 27-41.

GALLAGHER Kevin (2011) "Regaining controls? Capital controls and the global financial crisis", Working Paper, University of Massachusetts Amherst, n²50, February.

GAMBLE, William (2011) "Brazil: warning signs of a credit bubble being ignored”, Moneylife, February 28.

GAULARD, Mylène (2011) L'Economie du Brésil, Paris: Bréal.

GRIFFITH JONES, Stephany (1998) Global capital flows, should they be regulated? New York: MacMillan press.

GRIFFITH JONES, Stephany, and Kevin GALLAGHER (2011) "Curbing hot capital flows to protect the real economy”, Mumbai, Economical and Political Weekly, January 15: 12-14.

GRISLAIN, Nicolas, and François JACQUET-SAILLARD, (2008) "Carry-trades et évolutions récentes du yen", Trésor Eco, n³3, April, 137-146.

IEDI (2011) “O novo boom do endividamento externo brasileiro”, Carta IEDI n472, June 17.

IPEA (2011) Indice das expectativas das famílias, Rio de Janeiro, February 1.

JONGLEZ, Olivier (2008) “Appréciation réelle du taux de change dans les pays émergents”, Trésor Eco, $\mathrm{n}^{\circ} 35$, abril, 147-154.

KALTENBRUNNER, Annina (2010) "International financialization and depreciation: the Brazilian real in the international financial crisis”. Competition and Change, Vol. 14 (3-4), December, 296 323.

KOKENYNE, Annamaria (2010) "Face aux afflux croissants de capitaux", Finances et Développement, Washington, International Monetary Fund, September, 57-58.

La Nación (2009) "Krugman advierte sobre una burbuja brasileña”, Buenos Aires, December 6.

MANARIN D'AGOSTINI, Luciano Luiz (2010) “A bolha imobiliária no Brasil está formada”, Economia e Tecnologia, vol. 23, October-December, 41-53. 
MARSHALL, Paul (2011) "Brazil may be heading for a subprime crisis", Financial Times, February 21. MUNHOZ, Vanessa da Costa, and Gilberto LIBÂNIO (2009) "Volatilidade dos fluxos financeiros e fuga de capiais: uma análise exploratória da vulnerabilidade externa no Brasil”, Texto para Discussão, Universidade Federal de Minas Gerais, $\mathrm{n}^{\circ} 371$, November.

PALLEY, Thomas (2009) "Rethinking the economics of capital mobility and capital controls", Revista de Economia Política, vol. 29, n³, July-September: 15-34.

SONAGLIO, Claúdia Maria, Carlos Otávio ZAMBERLAN, João Eustáquio DE LIMA, and Antonio C. CAMPOS (2010) "Evidências de desindustrialização no Brasil: uma análise com dados em painel”, Economia Aplicada, vol.14, n 4 , October-December: 347-372.

SUBRAMANIAN, Arvind, and John WILLIAMSON (2009) "The fund should help Brazil to tackle capital inflows", Financial Times, Washington, Peterson Institute for International Economics, October 25 .

SUTTLE, Philip (2010) "Capital flows to emerging market economies", Research Note, Washington, Institute of International Finance, October 4.

TOBIN, James (1978) “A proposal for international monetary reform”, Eastern Economic Journal (Eastern Economic Association), July, 153-159.

\section{DATA WEBSITES:}

Banco Central do Brasil: www.bcb.gov.br

FipeZap: www.zap.com.br

Gecodia: www.gecodia.com

IEDI: www.iedi.org.br

IIF (Institute of International Finance): www.iif.com

Ipeadata: www.ipeadata.gov.br 